\title{
The Development of Social Study Model through Online on Early Child Education Program at Muhammadiyah University Student
}

\author{
Sutrisno", Diana Nomida Musnir, Nurdin Ibrahim \\ State University of Jakarta, Indonesia \\ Received July 9, 2019; Revised September 9, 2019; Accepted September 16, 2019
}

Copyright $\odot 2019$ by authors, all rights reserved. Authors agree that this article remains permanently open access under the terms of the Creative Commons Attribution License 4.0 International License

\begin{abstract}
The aim of the study was to develop a learning model, so that it could become a guideline in learning Social Sciences for students of the Early Childhood Education Study Program. Renewal in the model developed innovates conventional learning models into modern learning. The method used in this study is Research and Development, with learning prototype products developed in the form of e-modules. The results of the study after being tested in the three educational institutions used as the place of research were obtained; (a) pretest $34.94 \%$ posttest $80.12 \%$, difference of $45.18 \%$, (b) pretest $29.26 \%$ posttest $79.26 \%$, difference of $50 \%$, (c) pretest $43.67 \%$, posttest $86.57 \%$, difference of $42.9 \%$. The conclusion is that effectiveness and feasibility of the model are feasible and effective to be used in social studies learning.
\end{abstract}

Keywords Development, Model, Learning, Online

\section{Introduction}

The results of the preliminary study found that lecturers did not use the online media as much, as a tool to assist the teaching and learning process. (Bhukuvhani, Chiparausha, Zuvalinyenga, \& ICT, 2012) said the use of electronic information resources by proven work as evidenced by the results. However, there is need to mount more and frequent electronic information on training workshop resources. In fact, in the field lecturers have not utilized online media optimally as learning media to facilitate students in learning. (Dabbagh \& Fake, 2017) stated online learning: concepts, strategies, and applications offer a unique approach to thinking about teaching and learning in online and Web-based contexts. (Bonnici, 2016) Carey's predictions are rooted in evidence backed by research in both higher education and technological advancement.

Based on the opinion of Dabbagh and Carey, it can be explained that viewed from all components in the learning system is an important thing in the learning process both carried out online and with the process of the steps of the learning system. (Bello \& Aliyu, 2012) stated "Dick and Carey Model proved to be more efficient than traditional lecture methods". (Dabbagh \& Fake, 2017), teaching students to become effective self-regulated learners may help them acquire basic and complex personal knowledge management skills that are essential for creating, managing, and sustaining PLE using a variety of social media, actually ICT media can be integrated in learning activities.(Ghavifekr \& Rosdy, 2015)stated they recognize that they do possess knowledge; students need to access as soon as possible the material they want, to answer the needs of these students, the lecturers need to innovate in learning, alternatively that can be done by utilizing the media. Online is as a place to load learning innovation results. (Getuno, Kiboss, Changeiywo, \& Ogola, 2015) explained teaching and learning worldwide has gone through a transformation that has seen traditional delivery of learning material augmented by the use of Information and Communication Technologies.

Through online media students can learn by exploring and discovering what is being learned, so that there is a process of observing, looking for information. (Sangra \& González-Sanmamed, 2011) explained it is a contribution of ICT to teaching and learning processes higher in the schools that have integrated ICT as an innovation factor. To attain the highest level of implies that school not only has to modernize the technological tools, but also has to change the teaching models. (Pegu, 2014) said which can be shared by means of ICT, can foster better teaching.

Traditional teaching that has not utilized ICT as one of the media in learning will hinder the progress of student learning in higher education, answering these problems. 
(Oluwaniyi, Afeni, \& Lawal, 2015) explained the web-based asynchronous e-learning system will reduce the classical learning system and save time and resources. (Al Gamdi \& Samarji, 2016) said overcoming external sources barriers is mandatory to progress to overcoming the remaining barriers so that the focus is more on the scientific dimensions and opportunities of e-learning rather than on the logistics. Based on the reality in the field, efforts need to be made to innovate the development of learning models that will simplify and make learning more effective.

The use of information and communication technology is really needed in the world of education and learning in higher education, given the convenience that will be obtained, the need for lecturers and students to be able to utilize online media to develop learning models, in general, colleges have modern internet networks to develop learning through online is no longer a barrier to. (Suman, Chawan, \& Meshram, 2011) explained now a day's most of the educational centers (universities, institutes, colleges and schools) are using some eLearning tools as an integral part of their learning systems; to enhance their traditional learning systems or use an alternative approach to virtual learning environments.

Learning in the era of information and communication technology has an impact on the development of learning technology, and learning no longer relies on one source in the form of textbooks, but can also be collaborated with the development of multi-media, implementing more varied, effective and enjoyable learning. (Embong, Noor, Hashim, Ali, \& Shaari, 2012) stated in classrooms, teachers and students will start to value the convenience and accessibility of e-books. Technologists can expand e-Book usage among large number of children through creating (Ushakov \& Studies, 2017)awareness of e-Book usability.

Innovation in learning is the development of new ideas that need to be communicated within the world of education. (Foote, Neumeyer, Henderson, Dancy, \& Beichner, 2014) explained since instructors tend to make modifications, find out more about this process can help in the development of resources to support instructor adaptation of the reform to their local circumstances in productive and successful ways. Diffusion contains elements: (1) idea ideas, (2) products, (3) techniques, (4) technology, (5) communication channels, (6) media, (7) time, (8) socio-cultural systems, (9) customs, customs and norms.

The advantages of online learning need to be taken into account. Laurie (2016) stated online course offerings prepared and presented with student ability to review speed-based results in academic success based on actual learning and knowledge acquisition (Barac, 2015) stated A bespoke course design framework for implementation is offered to students to offer blended or online offerings in response to increasing demand for universities to offer. $21^{\text {st }}$ century learning environments, there is a gap between expectations and reality in the field, it is necessary to do research on the development of social studies learning models through online for students, according to the study. This research is designed to have 4 problem formulations that will be used as a basis for solving problems in this study: (1) how to develop learning strategies in developing social studies learning models through online, (2) how the implementation of social studies learning through online, (3) how the product process prototype of social studies learning through online, (4) how the effectiveness of social studies learning models through online.

\section{Literature Review}

Traditional learning models use chalk media, black and white markers, then move to the Overhead projector, the era of information and communication technology will facilitate. (Al-Hadithy \& Sciences, 2015), stated the world has witnessed the boom of revolution in information and communication technology during the last decade. Lecturers can make power points with laptop media to present material to students, lecturers can develop learning models even better, if the power points are made equipped with other products such as e-modules and place them on blogs so that it will greatly facilitate students in learning. (Alsadhan, Alhomod, \& Shafi, 2014) stated that the advancement in multimedia and information technologies also has impacted the way of imparting education. This advancement has led to rapid use of e learning systems and has enabled greater integration of multimedia content into e learning systems.

Online learning can be done by utilizing blog media as a place to convey information to students. (Kiliç \& Gökdas, 2014) stated that Blogging has become a popular tool within an educational context. Theoretical support that has been discussed, in this study the researcher uses the blog media to place learning materials in the form of e-modules and other media which are used as learning support materials for students, for example: (1) syllabus, (2) learning plans, (3) modules. The concept of developing a learning model, can be interpreted as a thought to answer the challenges of the development of science and technology that experienced such rapid changes (Umeagukwu Emmanuel \& Ngozi, 2014) stated the outcome of the study shows that ICT really has impacted positively and progressively on universities Curricular.

Learning that uses the advancement of information technology can strengthen the fulfillment of learning needs for students and lecturers in developing learning organizations so that the adoption of advances in science in ICT technology becomes a necessity, such progress can be seen as good issues and will have a positive impact on learning. (Cho et al., 2015) stated the components of the learning system design that is developed is a learning model that can be realized in the form of a blog product, 
which contains: videos, images, power point articles, emodules, learning strategies or other materials that are still relevant to learning. (Ushakov \& Studies, 2017) stated the efficiency of e-learning, observed recently, has boosted a strong demand for e-learning systems at higher. The development of the learning model adopted from the theory of learning model development is done as a foothold for finding learning models that suit the needs of students and the development of science and technology. Development of learning models must pay attention to the context and characteristics of students.(Wani \& Ali, 2015) When mobile phones were introduced in the world markets, little did one expect that these small handheld devices would transform the world as we knew it. This small innovation transformed the lives of millions of people.

Telecommunications / internet media which so far have not been maximally empowered as a means to facilitate lecturers and students in tool learning activities, the use of online media in learning will be easier and more enjoyable, for students and lecturers. As a facilitator the lecturer can post / enter learning objectives, syllabus, lesson plans, power points, videos, assignments, results of assessment and measurement and other information, with the use of online media learning media no longer depends on the place and time of study, students can learn wherever and whenever they wish to learn.(Tsai, Lin, \& Lin, 2018) said sing digital and internet services outside the classrooms, but it has also been attained as a theme for prospective learners in a more convenient way.

The online learning model has three main things which are very important, namely: (1) lecturers as material guiding actors, (2) students as recipients, (3) administrators online learning models are learning models that are integrated between electronics and printed material learning resources.(Becker, Newton, \& Sawang, 2013) stated there are three key factors that represent barriers to e-learning: the nature of e-learning as a learning approach, the use of technology, and concerns about lack of time and potential interruptions when trying to complete e-learning. Although online learning has limitations, universities need to adopt it. (Li, Qi, Wang, \& Wang, 2014) stated that e-learning facilitates higher levels of learning, better aspects of innovative thinking and critical thinking. (Hattie \& Donoghue, 2016) stated that e-learning facilitates higher level learning better. Online learning is a strategy for carrying out the entire learning system from preparing, planning, communicating, providing media, learning materials, learning time which is carried out sequentially and systematically so that it can achieve learning goals, then can be seen in the learning model:

\subsection{Dick and Carey Model}

Dick and Carry make the components of the learning system sequentially from the beginning to the end of the learning process as follows: (1) identifying learning objectives, (2) analyzing instructional, (3) analyzing student characteristics and learning contexts, (4) formulating specific learning goals, (5) developing assessment systems, (6) developing learning strategies, (7) developing and selecting instructional materials, (8) developing formative evaluations, (9) conducting revisions to learning programs.

\subsection{IDLF Model}

Dabbagh, The IDLF for online learning also promotes the idea of a systematic, explicit process providing the developer with a knowledge opportunity to learn more about his leaners, instructional settings, pedagogical approaches, and high effectiveness. (Noesgaard \& Ørngreen, 2015) said that the research examining the effectiveness of e-Learning had increased in recent years. The IDLF model sees learning with a socio-cultural context approach, so this model is very relevant to the development of social science learning.

\subsection{Conceptual Design}

The design of the Dick and Carey learning model is combined with learning that utilizes the development of information and communication technology that emphasizes multimedia learning with the framework of integrative learning design (IDLF) developed by Dabbagh and Bannan-Ritland, the characteristics of this learning model are: (1) learning process virtual classroom, (2) raising social issues, (3) utilizing various types of delivery. The range of the conceptual model can be seen in Figure 1. 


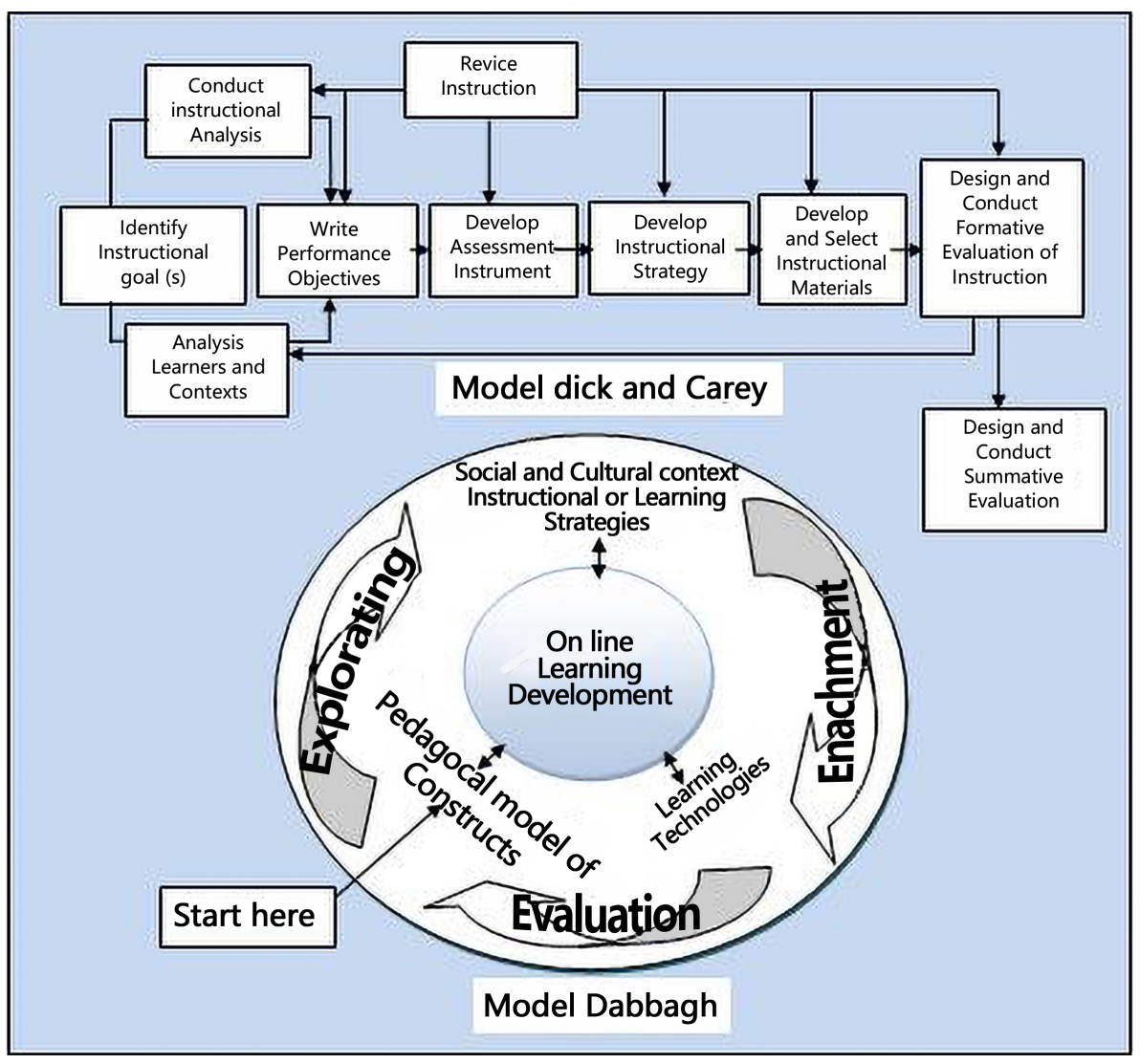

Figure 1. Conceptual Design

The IDLF model is very relevant for learning activities in higher education, this is due to the fact that most tertiary institutions already have adequate internet networks, and the characteristics of the IDLF learning model raise social problems, so it is very relevant to present a course in developing social science learning. The benefits of learning using the integrative learning design framework (IDLF), learning can be carried out using digital media and telecommunications, for urban areas, and adult learning such as digital media and communication students such as the internet are not foreign items from students, therefore this model is very good for students.

Collaboration between two learning models namely Dick and Carey and Dabbagh and Bannan-Ritland models, the design of the development model is expected to answer the challenges of the development of science in information technology and communication with the development of information and communication technology so that lecturers must be able to use the multimedia to learning activities, with the hope that the learning presented by the lecturer will be more interesting and bring a large impact on the improvement of student learning competencies. The use of information and communication technology creates changes and development in learning, lecturers who previously presented learning in a conventional manner using one source in the form of books, so that the changes and development of learning associated with learning technology can be presented better.

The flow of information that develops so quickly, brings the result of changes in learning paradigm, with these conditions, the development of absolute online learning to be done, in the era before the development of information and communication technology, students conduct learning in conventional ways, conditions that depend on lecturers, books, time and place to study, but now students can study online using internet media that can use various media so the learning conditions will be more effective and efficient. Teaching materials arranged and published online through blog products, learning can also be done in class or outside the classroom, the material to be learned by students can be accessed whenever and wherever they will learn, so learning will be more effective and flexible, and not limited by time, but face-to-face is still needed, as a place to communicate and ask problems found in learning.

\subsection{Procedural Design}

The design of the procedural model in this study is illustrated by three stages of model development, each of which is revised to obtain better results, while the design drawings of the structural model are described as follows: 


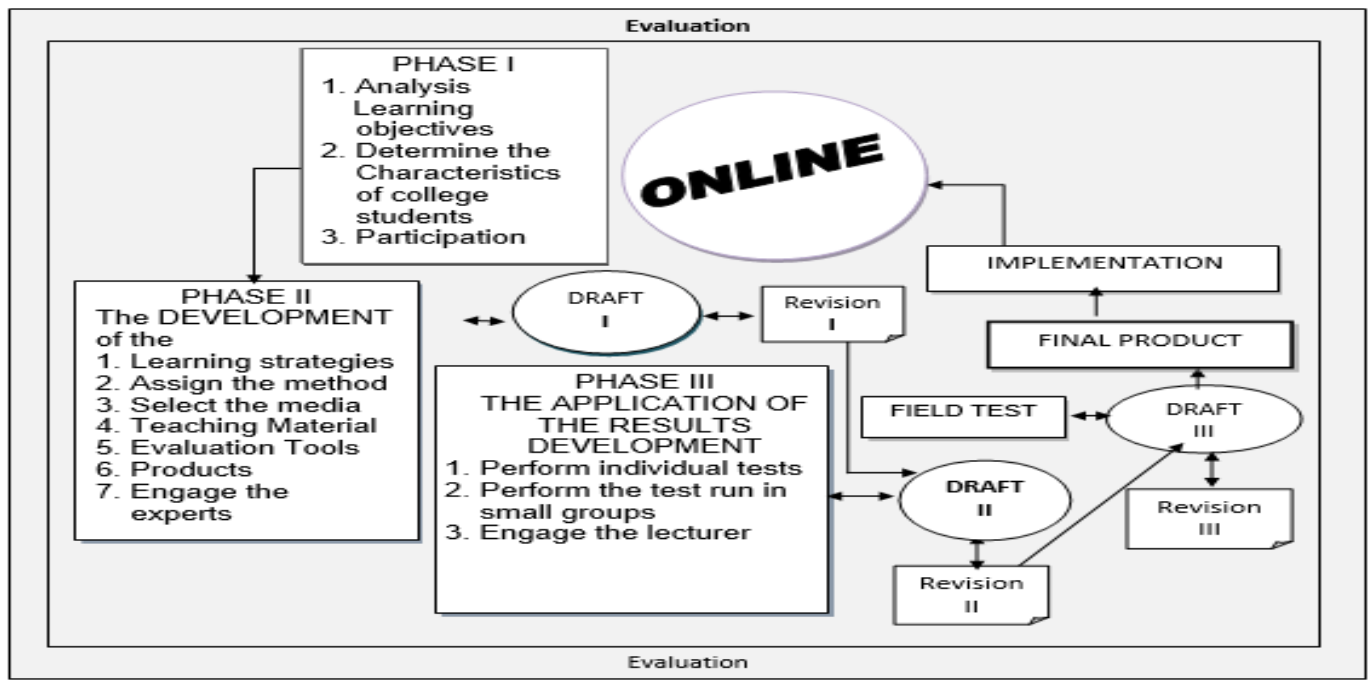

Figure 2. Procedural design

Development of the Social Sciences learning model through online in Figure 4 can be explained as follows: (1) Preliminary research (2) Development, (3) Application of development results, (4) Realizing revised results, (5) ) the field after being deemed feasible is made into the final product. (6) Evaluation

\subsection{Final Model}

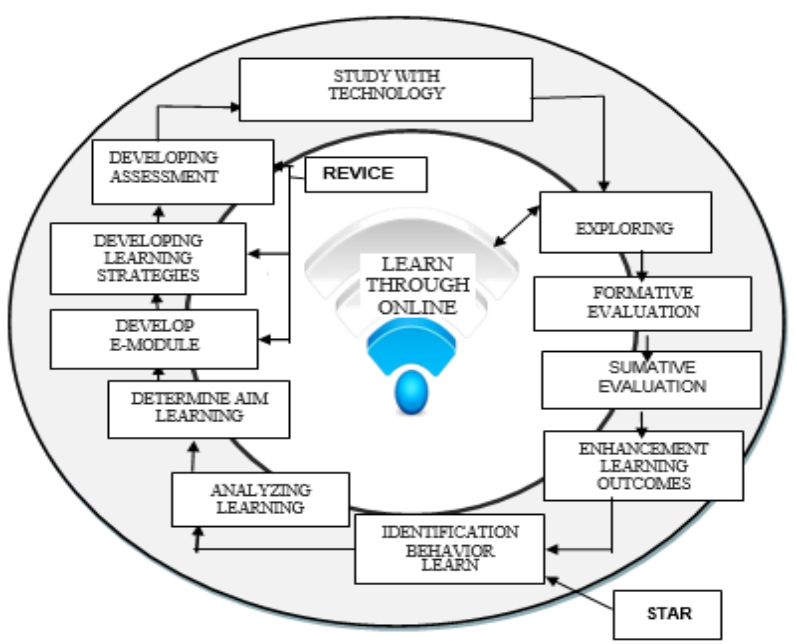

Figure 3. Final Model

Based on the description of the conceptual model and procedural models, the final model is determined.

\section{Research Methods}

This study uses the Research and Development method (using qualitative and quantitative approaches). One form of research, that is used to answer the problems faced by the world of education, which is caused by the advancement of science and technology so that the learning process needs to adjust to these developments, education is useful to improve the quality of learning, by discovering and developing new products, which are used to assist students in learning, the point is that learning is done by students to be easy, effective and efficient, do learning, learning is carried out with multi-media so that it has a positive impact on students with the conditions that will occur, learning is more varied.

\section{Research Results and Findings}

The results of field tests to test the effectiveness of student achievement using prototype learning products through online shows a very high increase, so it can be stated that the prototype developed makes it easier for students to study optimally, this model is designed to suit the learning needs of students. Utilizing ICT in learning, activities of students is helped to overcome study time, place of learning and availability of teaching materials. The results of the effectiveness test on 3 educational institutions showed an increase in good learning outcomes, the results of the effectiveness test on the model developed can be seen in table 1. 
Tabel 1. Effectiveness Test Results

\begin{tabular}{|c|c|c|c|c|c|c|c|}
\hline No. & Activities & $\begin{array}{c}\mathrm{N} \\
\text { Respondents } \\
\end{array}$ & Average Value & $\begin{array}{c}\text { Standard } \\
\text { Deviation }\end{array}$ & $\mathrm{T}$ Value & Df & $\begin{array}{c}\text { Sig. T-test (2 } \\
\text { Tailed) }\end{array}$ \\
\hline 1 & Pre test & 29 & 10,48 & 3.51142 & \multirow{2}{*}{-24.507} & \multirow{2}{*}{28} & \multirow{2}{*}{0,000} \\
\hline 2 & Post test & 29 & 24,10 & 2.39560 & & & \\
\hline 3 & Pre test & 27 & 10,52 & 1.96841 & \multirow{2}{*}{$-22,715$} & \multirow{2}{*}{26} & \multirow{2}{*}{0,000} \\
\hline 4 & Post test & 27 & 23,78 & 2.20721 & & & \\
\hline 5 & Pre test & 31 & 13,55 & 3.85434 & \multirow[b]{2}{*}{-18.727} & \multirow[b]{2}{*}{30} & \multirow{2}{*}{0,000} \\
\hline 6 & Post test & 31 & 26,84 & 1.71458 & & & \\
\hline
\end{tabular}

Recapitulation of the above count results can be drawn the conclusion:

1. Test free test and posttest Test results in the Early Childhood Education Teacher Education study program at the University of Muhammadiyah Pontianak indicate that the average value of the final Test and differ significantly with initial test value: (24.10 > 10.48); and the $t$ value 0.000 smaller than $0.05(0000<0.05)$. Thus that the models used and proven effective to test hypothesized that applied.

2. Test free test results and posttest tests on the Early Childhood Islamic Education Study Program at the Pontianak State Islamic institute indicate that that the average value of the final Test and differ significantly with initial test value: $(23,78>10,52)$; and the $t$ value 0.000 smaller than $0.05(0000<0.05)$. Thus that the models used and proven effective to test hypothesized that applied

3. Test free test results and posttest tests at the Early Childhood Education Study Program at Tanjungpura University, Pontianak indicate that the average value of the final test is larger and different significant with the initial test value, namely: (26.84> 13.55); and the value of $t$ count 0,000 smaller than $0.05(0,000<0$, $05)$. Thus that model used and hypothesized to prove effective based on testing applied. Learning outcomes indicate how students are prior to being given online learning Getting unsatisfactory learning outcomes, but after students take learning through online obtain good learning outcomes, as seen in figure 4 .

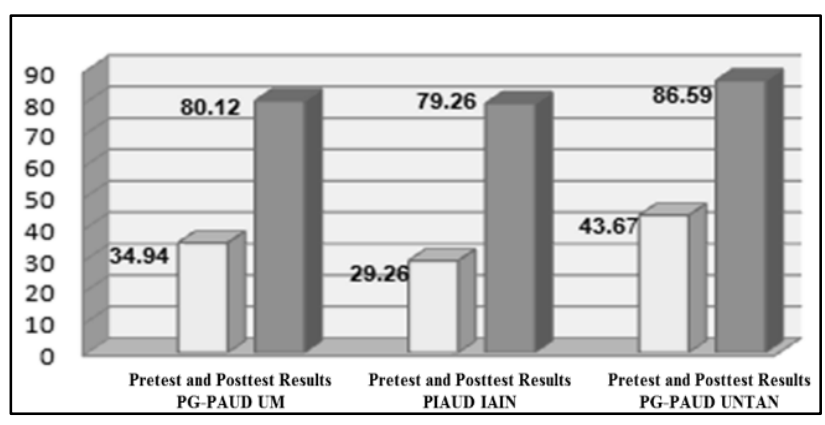

Figure 4. Field Test Results

The results of field tests show that the effective online learning model to be implemented in higher education is because universities generally have an internet network, so students in their daily activities have used online media to communicate. Reality in the student field in the era of ICT; (1) have tools related to online media, (2) students are faced with the world of work related to online media, and this fact becomes a supporting factor for the implementation of online learning. The conditions faced by students indicate the needs of students are very high for online learning, the responses of the students who are used as respondents are illustrated in Figure 5.
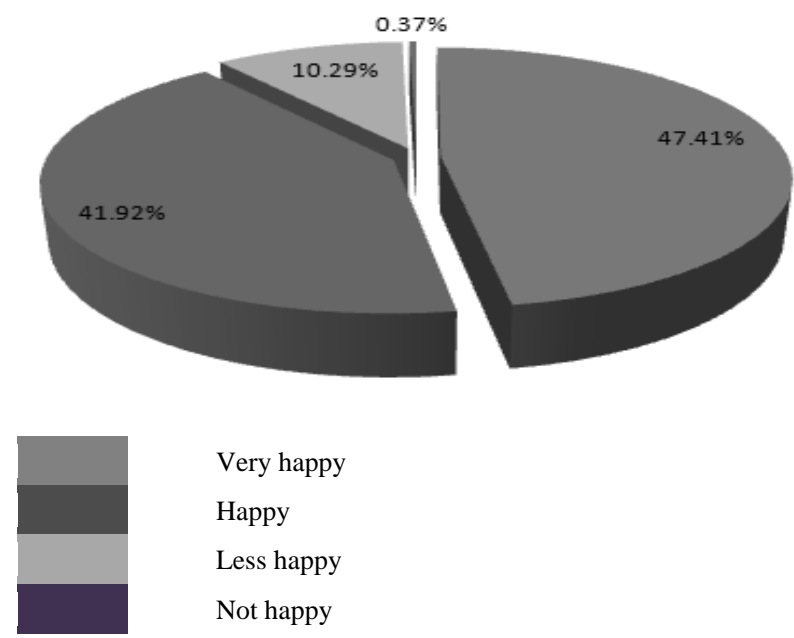

Figure 5. Student response Against Learning Models

The development of the Social Sciences learning model for students through online research results found that online learning is favored by students. (Fırat, Kılınç, \& Yüzer, 2018) stated the level of intrinsic motivation among students is open and distance education. The conclusion of the research conducted by Firat is that the level of intrinsic motivation of distance education students in the e-learning environment is decisive.

The strength of the model produced is, (1) Learning can be carried out when and wherever students and lecturers are not bound by time and place, (2) the material presented can be more, (3) learning becomes more varied (4) not bound by books package. The limitation in this study is that to implement maximum online learning needed an adequate internet network, from the results of this research the organizers have not maximally provided ICT infrastructure. (Islam, Beer, \& Slack, 2015) said there are 
many within this perspectives that give cause for concern; they have been grouped as challenging higher facing education institutions oral of Educational Technology. (Kebritchi, Lipschuetz, \& Santiague, 2017) stated the five broad categories are: learning style and cultural challenges, pedagogical e-learning challenges, technological challenges, technical training challenges and time management challenges, to address these challenges in online education, higher education institutions need to provide professional development for instructors, trainings for learners, and technical support for content development.

The most important barriers to online learning obtained from extensive literature surveys and developing survey instruments that combine barriers that are achieved for the effectiveness of learning through online are better, which need to be considered in learning through online are: (1) organizers must provide adequate infrastructure (2) designing learning that must be carried out, because online learning must provide a variety of varied sources, (3) paying attention to the learning needs of students. (Sleator, 2010) stated cost and quality are undoubtedly the most significant drivers of successful integration of ICT in higher education, from the statement, costs also become one of the factors in the implementation of learning through online. However, ICT progress cannot be avoided by universities, given the high learning needs, learning uses technology intended to be used, using technology to enhance learning. Shana (2015) stated this is especially true in an academic environment, where the Internet is often used as a tool to facilitate deeper learning. Learning carried out through online is very popular this century and more and more educational technology experts offer web-based learning.

The responses of students who were used as respondents in the study of learning development through online students preferred learning that was conducted online. (Alias, Zakariah, Ismail, \& Aziz, 2012) stated the results of the study indicate that respondents acquire and need good application of all electronic service quality the dimensions in fulfilling their needs and satisfied them. The results of the study showed that respondents obtained and needed good applications from all ten dimensions of electronic service quality in meeting their needs and satisfying them, from the results of research conducted by Alias from Malaysia found the same thing that students really need learning services through online. The learning model implemented through online brings students to conduct learning activities, so the intended learning objectives can be achieved, in line with the results of this assessment,

\section{Conclusions}

Lecturer learning strategies explain learning models through online with e-module products, learning activities begin with, (1) Initial activities, lecturers are provided with 10 minutes, lecturers explain learning objectives, then do apperception with question and answer, to find out student mastery competencies to the material, (2) core activities, using the task method, discussion, question and answer study time provided 70 minutes, students conduct learning activities online by exploring through internet media to find information, to answer tasks and questions that have been provided, closing activities 20 minutes are provided for daily evaluation activities to conclude the results of learning, students are motivated to study outside the classroom by utilizing products in the form of e-modules provided as well as by looking for other sources available on the internet.

The implementation of the learning is generally facilitators deliver material with the method of divorce, discussion, and question and answer and media that are used in focus, this reality makes the learning atmosphere less varied so as to lead to maximum achievement and learning objectives, with online learning the implementation of learning is modified, for learning in the classroom through the initial, core and closing activities, the media used by commuters / laptops, android phones and using the internet, the methods used are the lecture method, discussion, question and answer, the task of exploring knowledge resources online to complete learning tasks, then adding field practice assignments to improve student skills.

Process and Prototype Products through online learning. First, pay attention to the components of the learning system: (strategies, teaching materials, learning facilities and infrastructure, lecturer competencies, student characteristics) show increased learning outcomes. The second conducts preliminary research to find out the learning needs and conduct an analysis of the learning process to obtain information on weaknesses and strengths in the learning process, making learning designs. Fourth, the results of prototype learning design with forms of learning through online in the form of e-module products that are linked to blogs that are equipped with lecturer guidance and guidance for students, fifth, make revisions as a step to correct weaknesses that occur.

Prototype effectiveness, trial by involving Social Sciences experts, learning model design experts, the results of teaching materials contained in blogs are stated to be relevant to the learning objectives, while the results of trials on students who are categorized as fast learning or highest and moderate IP are very satisfying, but for students categorized as learning with slow rhythms or low IPs experiencing obstacles, it is necessary to provide treatment in the form of assistance by facilitators / lecturers and students who are categorized as fast learning or high IP related to the content of learning that has not been understood. The results of trials in small groups on effectiveness, in small group trials found results that students categorized as high and medium IP did not 
experience difficulties and learning outcomes were very satisfying but in students who had the lowest IP still had a little difficulty, thus learning through online is interesting for students, learning through online media is categorized as very helpful for students, because the presentation of material, and illustrations make it easier for students to find the desired knowledge so that they can improve student competence in accordance with the learning objectives. Field testing was used to see the effectiveness of the material developed, the results of field tests found that the development of positive learning outcomes was shown from the results of the initial test and the final test from three different educational institutions showing good learning outcomes. Based on the results of the field test it can be stated that the development of the IPS learning model through online is effective and feasible to implement, from the results of student responses to learning through great interest, so learning through online can help students in learning.

\section{REFERENCE}

[1] Al-Hadithy, T. M. J. P.-S., \& Sciences, B. (2015). The Traditional Vs. The Modern Translation Classroom: A need for New Directions in The UAE Undergraduate Translation Programs. 192, 180-187.

[2] Al Gamdi, M., \& Samarji, A. (2016). Perceived barriers towards e-Learning by faculty members at a recently established university in Saudi Arabia. International Journal of Information and Education Technology, 6(1), 23.

[3] Alias, N., Zakariah, Z., Ismail, N. Z., \& Aziz, M. N. A. (2012). E-Learning successful elements for higher learning institution in Malaysia. Procedia-Social and Behavioral Sciences, 67, 484-489.

[4] Alsadhan, A. O., Alhomod, S., \& Shafi, M. M. (2014). Multimedia based e-learning: Design and integration of multimedia content in e-learning. International Journal of Emerging Technologies in Learning (iJET), 9(3), 26-30.

[5] Barac, K. (2015). The Conceived, the Perceived and the Lived: Issues with 21st Century Learning and Teaching.

[6] Becker, K. L., Newton, C. J., \& Sawang, S. J. A. J. o. A. L. (2013). A learner perspective on barriers to e-learning. 53(2), 211-233.

[7] Bello, H., \& Aliyu, U. (2012). Effect of 'dick and carey instructional model'on the performance of electrical/electronics technology education students in some selected concepts in technical colleges of northern nigeria. Educational Research, 3(3), 277-283.

[8] Bhukuvhani, C., Chiparausha, B., Zuvalinyenga, D. J. I. J. o. E., \& ICT, D. U. (2012). Effects of electronic information resources skills training for lecturers on pedagogical practices and research productivity. 8(1), 16-28.

[9] Bonnici, L. J. (2016). The End of College: Creating the Future of Learning and the University of Everywhere,
Carey, K. New York, Riverhead Books, 2015. Journal of Education for Library and Information Science, 57(3), 249-252.

[10] Cho, Y. H., Choi, H., Shin, J., Yu, H. C., Kim, Y. K., \& Kim, J. Y. (2015). Review of research on online learning environments in higher education. Procedia-Social and Behavioral Sciences, 191, 2012-2017.

[11] Dabbagh, N., \& Fake, H. (2017). College students' perceptions of personal learning environments through the lens of digital tools, processes and spaces. Journal of New Approaches in Educational Research (NAER Journal), 6(1), 28-36.

[12] Embong, A. M., Noor, A. M., Hashim, H. M., Ali, R. M., \& Shaari, Z. H. (2012). E-Books as Textbooks in the Classroom. Procedia-Social and Behavioral Sciences, 47, 1802-1809.

[13] Fırat, M., Kılınç, H., \& Yüzer, T. V. (2018). Level of intrinsic motivation of distance education students in e-learning environments. Journal of Computer Assisted Learning, 34(1), 63-70.

[14] Foote, K. T., Neumeyer, X., Henderson, C., Dancy, M. H., \& Beichner, R. J. (2014). Diffusion of research-based instructional strategies: the case of SCALE-UP. International Journal of STEM Education, 1(1), 10.

[15] Getuno, D. M., Kiboss, J. K., Changeiywo, J. M., \& Ogola, L. B. (2015). Effects of an E-Learning Module on Students' Attitudes in an Electronics Class. Journal of Education and Practice, 6(36), 80-86.

[16] Ghavifekr, S., \& Rosdy, W. A. W. (2015). Teaching and learning with technology: Effectiveness of ICT integration in schools. International Journal of Research in Education and Science, 1(2), 175-191.

[17] Hattie, J. A., \& Donoghue, G. M. (2016). Learning strategies: A synthesis and conceptual model. npj Science of Learning, 1, 16013.

[18] Islam, N., Beer, M., \& Slack, F. (2015). E-learning challenges faced by academics in higher education. Journal of Education and Training Studies, 3(5), 102-112.

[19] Kebritchi, M., Lipschuetz, A., \& Santiague, L. (2017). Issues and challenges for teaching successful online courses in higher education: A literature review. Journal of Educational Technology Systems, 46(1), 4-29.

[20] Kiliç, E., \& Gökdas, I. (2014). Learning through Blogging: Use of Blogs to Enhance the Perceived Learning of Pre-Service ICT Teachers. Educational Sciences: Theory and Practice, 14(3), 1169-1177.

[21] Li, F., Qi, J., Wang, G., \& Wang, X. (2014). Traditional classroom vs e-learning in higher education: Difference between students' behavioral engagement. International Journal of Emerging Technologies in Learning (iJET), 9(2), 48-51.

[22] Noesgaard, S. S., \& Ørngreen, R. (2015). The Effectiveness of E-Learning: An Explorative and Integrative Review of the Definitions, Methodologies and Factors That Promote e-Learning Effectiveness. Electronic Journal of e-Learning, 13(4), 278-290.

[23] Oluwaniyi, N. O., Afeni, B. O., \& Lawal, O. O. (2015). 
Development of an Asynchronous Web Based E-Learning System. Journal of Computer and Communications, 3(12), 84.

[24] Pegu, U. K. (2014). Information and communication technology in higher education in India: Challenges and opportunities. International Journal of Information and Computation Technology, 4(5), 513-518.

[25] Sangra, A., \& González-Sanmamed, M. (2011). The Role of Information and Communication Technologies in Improving Teaching and Learning Processes in Primary and Secondary Schools. Journal of Asynchronous Learning Networks, 15(4), 47-59.

[26] Sleator, R. D. (2010). The evolution of eLearning Background, blends and blackboard.... Science progress, 93(3), 319-334.

[27] Suman, N., Chawan, P., \& Meshram, B. (2011). CMS, LMS and LCMS for elearning. IJCSI International Journal of Computer Science Issues, 8(2), 1694-0814.

[28] Tsai, T. P., Lin, J., \& Lin, L. C. (2018). A Flip Blended Learning Approach for ePUB3 eBook-based Course Design and Implementation. EURASIA J. of Mathematics, Science and Tech. Education, 14, 123-144.

[29] Umeagukwu Emmanuel, O., \& Ngozi, E. B. (2014). An Analysis of ICT impact on the Curricular of Major Nigerian Universities in the Last Ten Years 2003-2013. International journal of science and Technology, 3(1).

[30] Ushakov, A. J. I. J. o. E. L., \& Studies, L. (2017). Learning Content Management Systems in Flt: Canadian Experience. 6(1), 25-32.

[31] Wani, T. A., \& Ali, S. J. J. o. g. m. r. (2015). Innovation diffusion theory. 3(2), 101-118. 